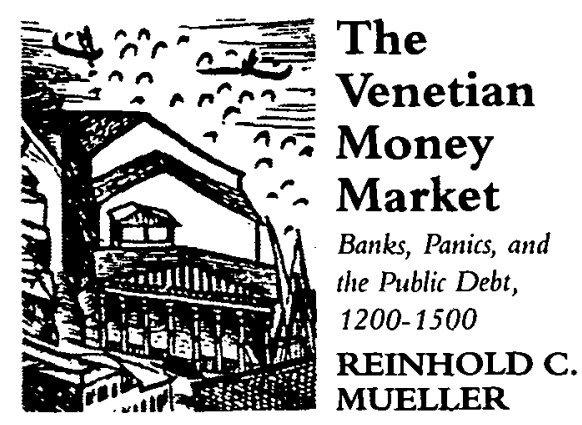

"The book will stand as the unavoidable model for the scholars who eventually do the history of banking and the public debt in other major commercial capitals."-Richard Goldthwaite, The Johns Hopkins University

$\$ 65.00$ hardcover

\title{
Safety First
}

Technology, Labor, and Business in the Building of American Work Safety, 1870-1939

\section{MARK ALDRICH}

"In the first extensive history of the Safety First movement, Mark Aldrich offers a unique and balanced view of changes in workplace safety. Applying his economist's eye and training, Aldrich describes these developments as a combined function of economic and employment changes, union and political pressure, corporate decision making, and the intervention of new professionals."-Walter Licht, University of Pennsylvania

Studies in Industry and Society

Philip B. Scranton, Series Editor

$\$ 49.95$ hardcover

\section{Alternative Tracks}

The Constitution of American Industrial Order, 1865-1917

\section{GERALD BERK}

“Berk's concise volume ... provides a reinterpretation along corporate liberal lines of the factors leading to the rise of the great interregional railroad systems in America during latter half of the nineteenth century." -Paul J. Miranti, Business History Review

$\$ 15.95$ paperback

\section{THE JOHNS HOPKINS} UNIVERSITY PRESS

Hampden Station, Baltimore, MD 21211

1-800-537-5487

http://jhupress.jhu.edu/home.html 


\section{Studies in American Political Development}

\section{Editors}

Karen Orren, University of California, Los Angeles

Stephen Skowronek, Yale University

Studies in American Political Development publishes high quality scholarship covering American political change and institutional development from a historical perspective. Articles focus on government institutions and their social, economic and cultural environment. The journal features in-depth original articles, which allow scholars to elaborate on the complex patterns of state-society relations. These longer articles also encourage an interdisciplinary approach-tying in relevant issues and related themes. In addition, SAPD recognizes the importance of comparative politics to the study of American institutions.

Semi-annual (ISSN 0898-588X)

Volume 11, 1997

Institutions $\$ 69.00$; Individuals $\$ 34.00$; Single Parts $\$ 36.00$.

Send orders to:

\section{Cambridge University Press 40 West 20th Street}

New York, NY 10011-4211

(Outside the USA, Canada, or Mexico:

Cambridge University Press, The Edinburgh Building

Shatesbury Road, Cambridge CB2 2RU, England.) 


\section{new from

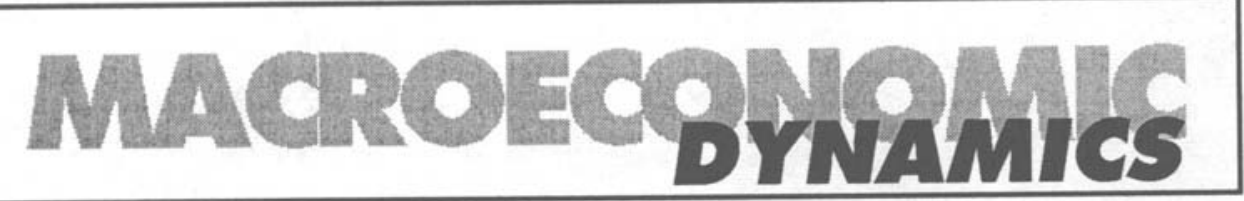

Editor

WILLIAM A. BARNETT, Washington University, St. Louis

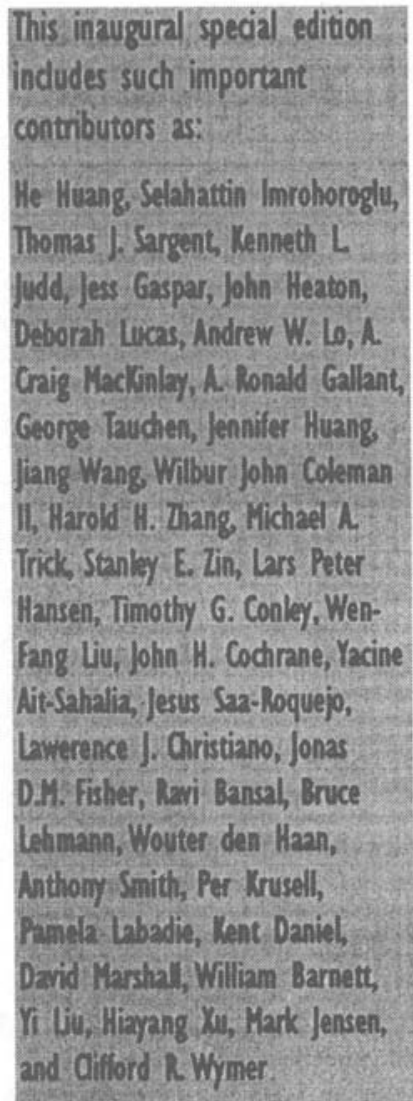

Mocroeconomic Dynomics will publish theoretical, empirical or quantitative research of the highest standard. Papers are welcomed from all areas of macroeconomics and from all parts of the world. Major advances in macroeconomics without immediate policy applications will also be accepted, if they show potential for application in the future. Occasional book reviews, announcements, conference proceedings and interviews will also be published. An electronic version of the journal will be published simultaneously with the paper version enabling immediate access to the best current research in macroeconomics.

Quarterly, ISSN 1365-1005

Subscription to Volume I, 1997:

Institutions \$149.00;

Individuals $\$ 75.00$.

\section{CAMBRIDGE} UNIVERSITY PRESS

40 WEST 20IH STREET - HEW YORK HY • 10011

CALL IOLL-FREE 800.872.7423, X-154 - e-mal: journals marketing@ cup.org • web sile: hitp://www.cup.org 


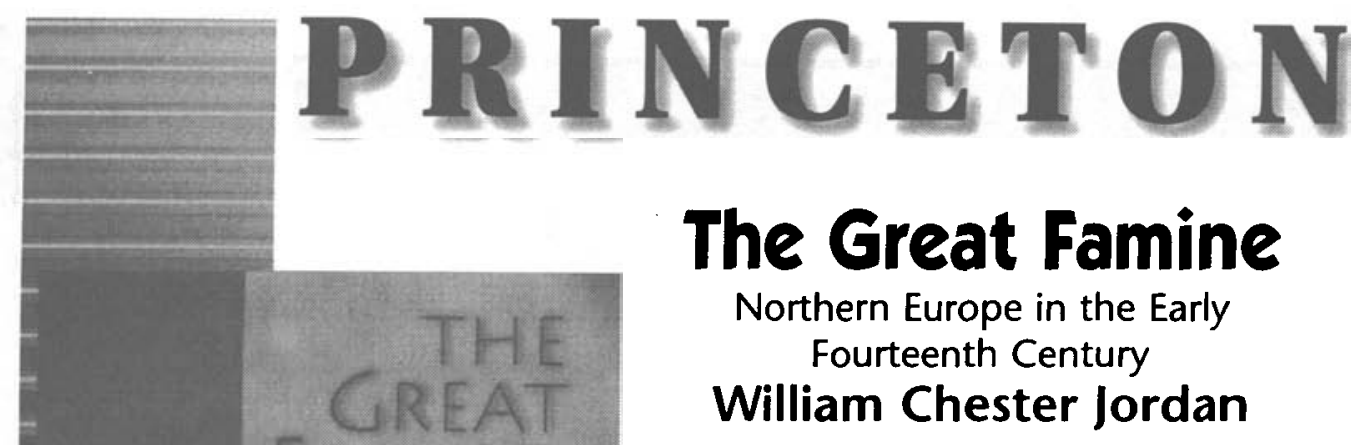

The horrors of the Great Famine (13151322), one of the severest catastrophes ever to strike northern Europe, lived on for centuries in the minds of Europeans. Until now, though, no one has offered a perspective of what daily life was actually like, nor has anyone probed far into the Famine's causes. Here the distinguished historian William Jordan provides the first comprehensive history of the Great Famine. In this revealing portrait of medieval life, we see the complex interplay of social and environmental factors that caused this disaster and allowed it to continue for so long.

"In this extraordinary book, William Jordan has crafted the most comprehensive study of the Great Famine. . . . There is no book. . . that provides as exhaustive a discussion of the Great Famine as does Jordan's work. It is a tour de force."-Teofilo Ruiz

Cloth \$29.95 ISBN 0-691-01134-6

\section{City of Capital}

Politics and Markets in the English

\section{Financial Revolution Bruce G. Carruthers}

While many have examined how economic interests motivate political action, Bruce Carruthers explores the reverse relationship by focusing on how political interests shape a market. He sets his inquiry within the context of late Stuart England, when an active stock market emerged and when Whig and Tory parties vied for control of a newly empowered Parliament.

Probing connections between politics and markets at both institutional and individual levels, Carruthers ultimately argues that competitive markets are not inherently apolitical spheres guided by economic interest but rather ongoing creations of social actors pursuing multiple goals.

Cloth $\$ 45.00$ ISBN 0-691-04455-4 


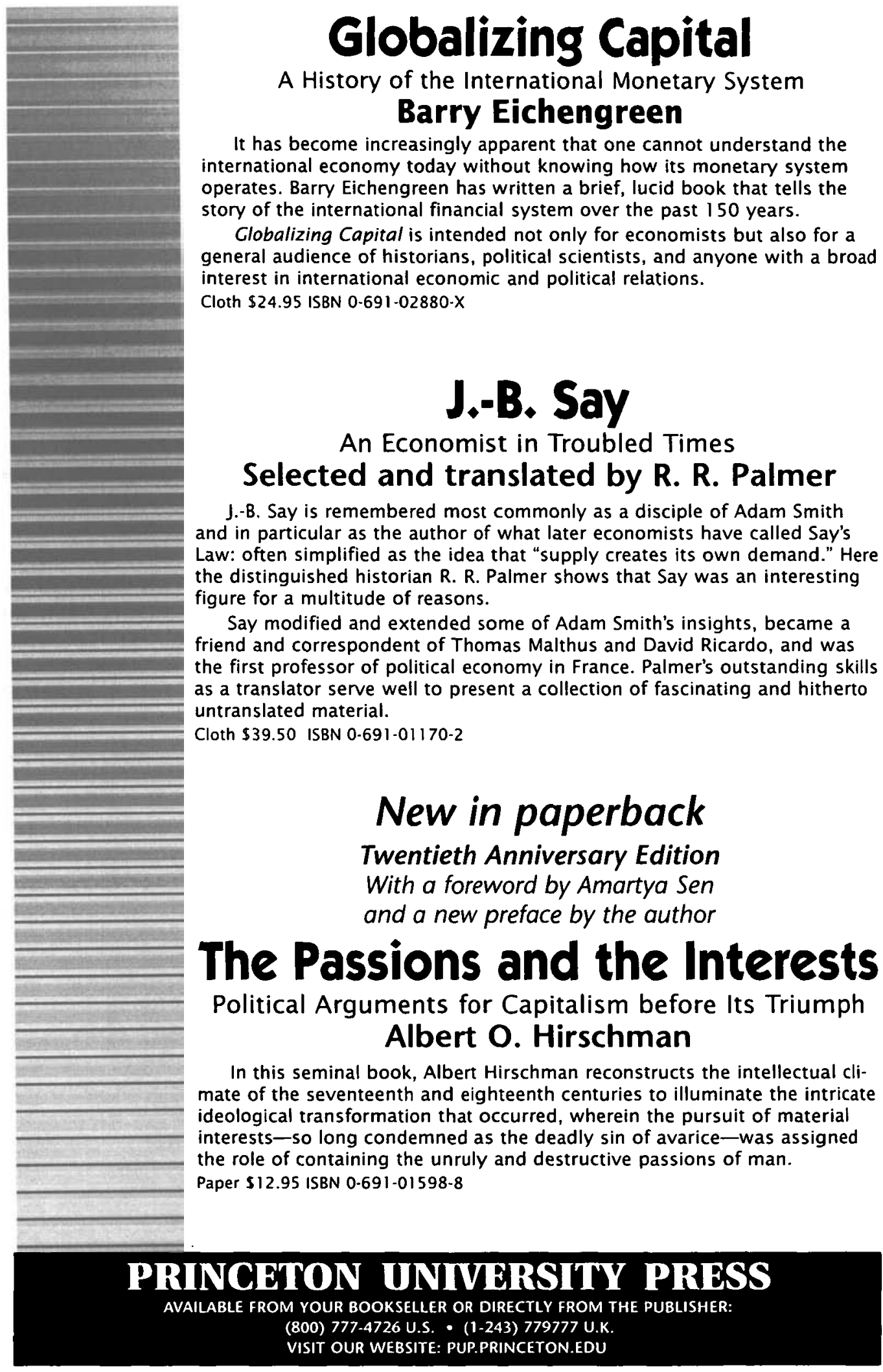




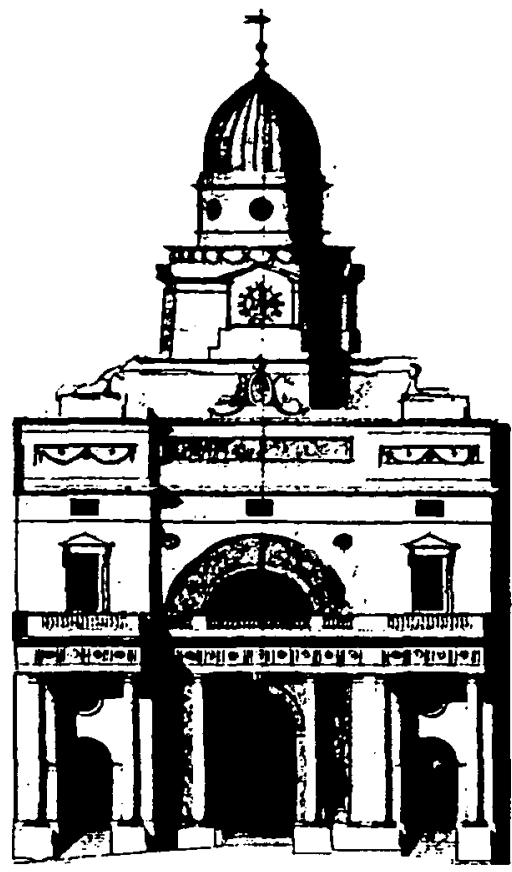

\title{
The University of Edinburgh
}

\author{
Graduate Studies in Economic \\ \& Social History
}

The Department of Economic and Social History in collaboration with the Departments of History and Scottish History offer a wider range of post-graduate degree courses in Economic and Social History leading to both Diploma/M.Sc and M.Phil-PhD.

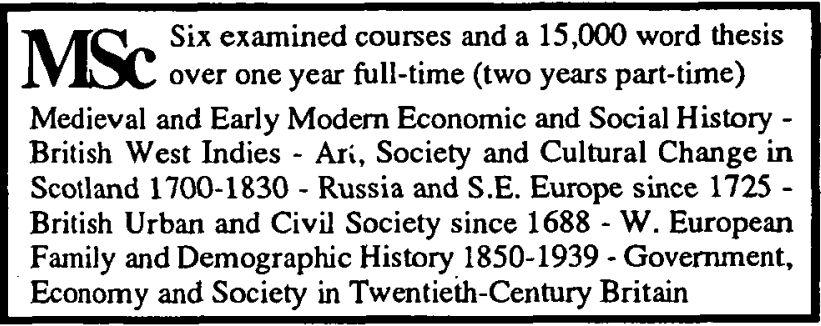

The doctoral programme offers supervision on a wide range of topics leading to a M.Phil or Ph.D.

Further details about these courses and about post-graduate study at the University of Edinburgh can be obtained from:

Dr M R Palairet, The University of Edinburgh, William Robertson Building, 50 George Square, Edinburgh EH8 9JY. U.K. Telephone + 44-131-650-3843. E-mail m.palairet@ed.ac.uk. or by reference to the Economic and Social History Department's intermethomepage: http://devito.ssml.ed.ac.uk/WWW/econ.html.

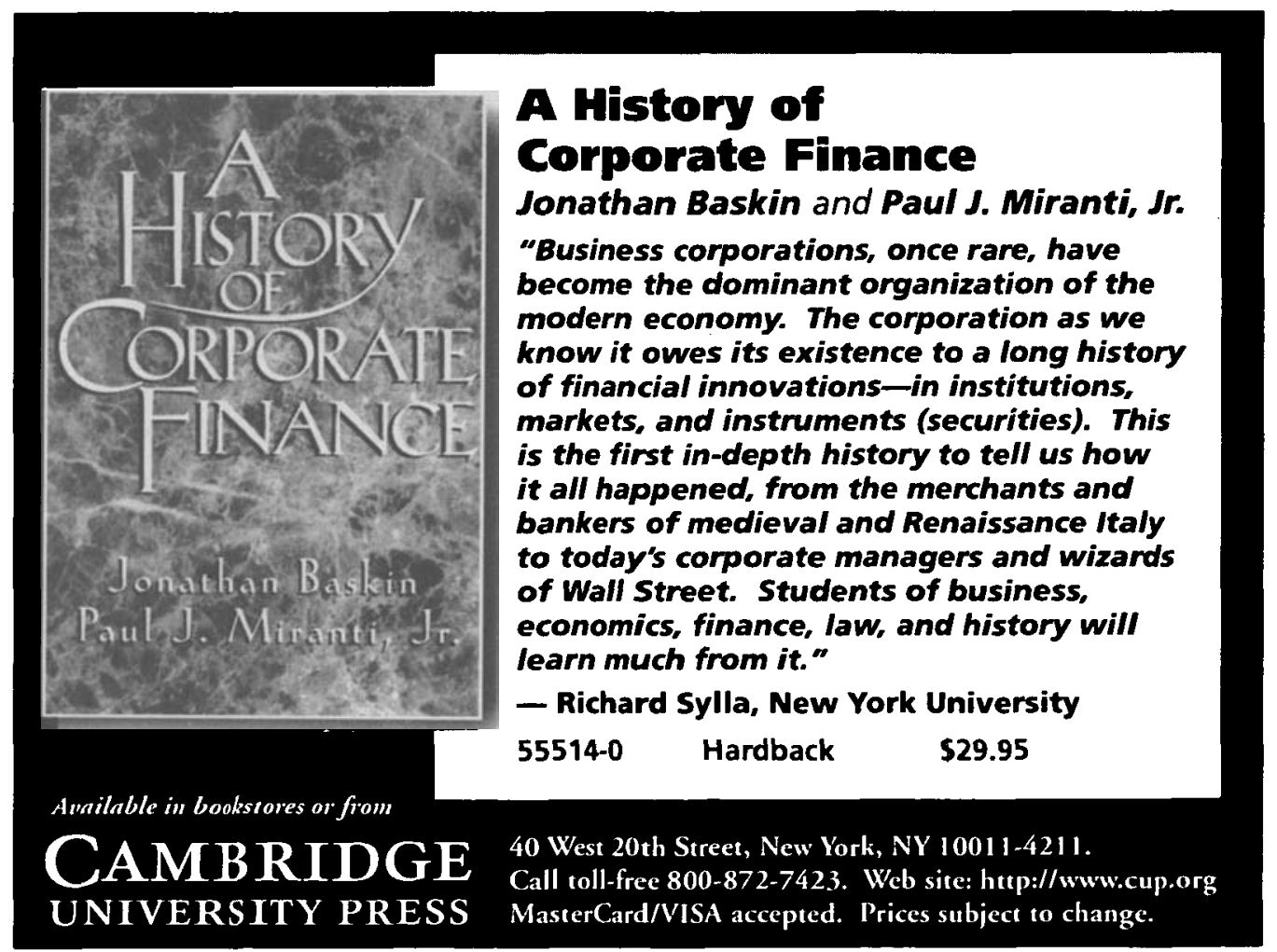




\section{NEW FROM CALIFORNIA}

Susan B. Hanley Everyday Things in Premodern

\section{Japan}

The Hidden Legacy of Material Culture

"A wonderfully original, cogently argued, and very readable book. Hanley provides persuasive answers to some of the largest questions historians have been asking about the relationship of premodern social and economic conditions to the modern development of Japan."

-Stephen Vlastos, author of Peasant Protests and Uprisings in Tokugawa Japan "A bold reinterpretation of Japan's social and economic readiness for modern development and industrialization."

-Irwin Scheiner, author of Japanese Thought in the Tokugawa Period, 1600-1868 $\$ 35.00$ cloth

At bookstones or onder 1-800-822-6657

\section{University of California}

\section{Thomas Spear} Mountain Farmers

Moral Economies of Land and Agricultural Development in Arusha and Meru

"Among the numerous contributions made by this book are its discussion of the politics of pseudotraditionalism, its tracing of the emergence of a Christian leadership, and indeed its whole reconsideration of the significance of missions and Christianity." - James L. Giblin, author of Environmental Control in Northeastern Tanzania, 1840-1940 $\$ 48.00$ cloth, $\$ 17.95$ paper, illustrated

\section{David W. Tandy Warriors into Traders}

The Power of the Market in Early Greece Using tools from political and economic anthropology, David Tandy argues that between about 800 and 700 B.C., a great transformation of dominant economic institutions took place involving wrenching adjustments in the way status and wealth were distributed within the Greek communities. Classics and Contemponary Thought, $\$ 45.00$ cloth

\section{Hesiod Works and Days}

A Translation and Commentary for the Social Sciences by David W. Tandy and Walter C. Neale

"For Greekless social scientists, which is just about all of them, including myself, this translation of Works and Days by a classicist rendering the text and an economist clarifying the meaning and significance will be of enormous value." $\$ 30.00$ cloth, $\$ 10.95$ paper 


\section{The Best in Economics}

\section{Democratic Sociallism and} Economic Pollicy

The Attlee Years 1945-1951

\section{Jim Tomlinson}

This book examines the cconomic policies of the Attlee Government, integrating the politics of economic policy-making with economic arguments. It stresses the importance of the government's drive for efficiency, and strongly questions the claim that in building a 'welfare state' the government neglected production.

Cambridge Srudies in Modern Economic History 3 55095-5 Hardback \$64.95

\section{Goldbugs and Greenbacks}

The Antimonopoly Tradition and the Politics of Finance in America, 1865-1896 Gretchen Ritter

Behind the late nineteenth century debate over what sort of financial system America should have, there was a broader dialogue about sectionalism, class relations, and the future course of the American economy and democracy. Professor Ritter contends that there was a distinctive and neglected political tradition in the United States - the antimonopoly traditionwhich was championed by nearly every major agricultural and labor group during the period from the Civil War until 1900.

56167-1 Hardback \$54.95

Europe's Economy Looks East

Implications for Germany and the

European Union

Stanley W. Black, Editor

Contributors: Stanley Black, Drusilla Brown, Alan Deardorff. Simeon Djankov, Robert Stern, Hari Vitas, Paulo Mauro, Dirter Schumacher. Mathias Moersch, PaulJ.J. Welfens, Thomas Bauer. Klaus Zimmerman, Michael Koop. 1. David Richardson, L. Alan Winters, Susan M. Collins, Wolfgang Maennig, Ellen Meade, Holger Wolf, Bruce Kogut. Jan Mlidek, Barry Bosworth, Robert LaLonde. Barmy

Eïchengreen. Hans-Jurgen Vosgeranu

\$7242-8 Hardback \$64.95

\section{An Economic Mistory of the Silk Industry, 1850-1930 Giovanni Federico}

This study documents the growth of the silk industry and the effects of western industrialization, technical progress and changing methods of production.

Cambridge Studies in Modern Economic History 5

58198-2 Hardback $\$ 59.95$
Competition and Monopoly in the Federal Reserve System, 1914-1951

A Microeccnomic Approach to Monetary History

Mark Toma

Many economists view competition among central banks as leading to an over-issue of money. This book claims that competition among Federal Reserve banks in the 1920s did not result in an over-issue problem. The US Congress imposed a more monopolistic structure on the Fed in the mid-1930s so that it could accomodate an increase in the revenue needs of the Treasury.

Studies in Monetary and Financial History

56258-9 Hardback \$49.95

\section{The Industrial Revolution in Scotland}

\section{Christopher A. Whatley}

Dr. Whatley assesses the nature and impact of early industrialization in Scotland, placing the Scottish experience within the context of the debate about the 'British' Industrial Revolution.

New Srudies in Economic and Social History 30

57228-2 Hardback \$34.95

\$7643-1 Paperback \$10.95

Now in paperback..

Trade and Traders in

\section{Musilim Spain}

The Commercial Realignment of the

Iberian Peninsula, 900-1500

Olivia Remie Constable

This volume surveys Iberian international trade with particular emphasis on commerce in the Muslim period and on changes brought by Christian conquest of much of Muslim Spain in the thirteenth century. Cambridge Studies in Medieval Life and Thoughts

Fourth Series 24

56503-0 Paperback \$22.95

\section{The Economy of Mlodern Indla, $1860-1970$}

\section{B. R. Tomlinson}

In this book, Dr. B. R. Tomlinson presents the first comprehensive and interpretative account of the history of economic growth and change in colonial and postcolonial India.

The New Cambridge History of India $\mathrm{II}_{\mathrm{i}} \mathrm{3}$

58939-8 Paperback \$19.95

\section{CHADWICK CAMPUS}

FOR 